\title{
2 Isolation and characterization of microsatellite loci \\ 3 in Sorbus aria (Rosaceae)
}

\author{
4 E. A. González-González • M. A. González-Pérez • \\ 5 E. Rivero $\cdot$ P. A. Sosa
}

6 Received: 9 April 2010/ Accepted: 17 April 2010

7 (C) Springer Science+Business Media B.V. 2010

8 Abstract Sorbus aria (L) Crantz (Common Whitebeam) 9 is native to Europe, east of the Balkans and in North 10 Africa; it is also present in the Canary Islands. To evaluate 11 the genetic diversity in natural populations of this vulner-

able species, nine novel polymorphic microsatellite markers were isolated from enriched libraries. Microsatellite loci were screened in 97 individuals from La Palma (Canary Islands) and Sierra Nevada (Granada, Spain). Examination of the microsatellite profiles shows that S. aria individuals have up to three alleles per locus. The cloned sequences in microsatellite loci confirmed the polyploidy status of the plants. The number of alleles ranged from 5 to 14 per locus. The phenotype diversities across loci $\left(H_{T}^{\prime}\right)$ ranging from 0.653 to 0.847 .

Keywords Sorbus aria $\cdot$ Microsatellite $\cdot$ Canary Islands . Genetic diversity $\cdot$ Conservation

The genus Sorbus L. (Rosaceae) includes small to medium sized trees from the North Temperate Zone. They are closely related to the commercial genus Malus and Pyrus (Robertson et al. 1991; Campbell et al. 1995).

Sorbus aria ( $L$ ) Crantz (Common Whitebeam) is native to Europe, east of the Balkans and in North Africa. It is distributed in mountain zones throughout almost all of Europe and part of Asia, from the Iberian Peninsula and Ireland to the Himalayas. It is also present in the Canary

\footnotetext{
E. A. González-González · M. A. González-Pérez · E. Rivero · P. A. Sosa ( $\square)$

Departamento de Biología, Universidad de Las Palmas de Gran Canaria, Campus Universitario de Tafira, 35017 Las Palmas de Gran Canaria, Canary Islands, Spain

e-mail: psoso@dbio.ulpgc.es
}

Islands. The trees are isolated and alone despite their widespread distribution; for this reason UICN has listed it as a "vulnerable species" (Cabezudo et al. 2000; Chester et al. 2007).

The European samples of Sorbus aria have been reported as diploids although the subgenus Aria (or S. aria aggregate) contains apomictic triploid and tetraploid species (Nelson-Jones et al. 2002). However, little is known about the genetic populations in the Canary Islands which have only been found on La Palma and Tenerife.

In this paper, we describe the isolation and characterization of 9 microsatellite markers in Sorbus aria and we indicate their effectiveness in identifying patterns of genetic diversity.

Genomic DNA for the development of markers and subsequent surveys were extracted from leaf tissue of 97 samples from La Palma (45) and Sierra Nevada (52) populations using a modified CTAB protocol (Doyle and Doyle 1987).

Microsatellite loci were developed by ATG GeneTic Inc. using biotin/streptavidin protocol (Khasa et al. 2000). Briefly, genomic DNA was digested with restriction endonucleases (Hae III or Rsa I with PshA I). A synthetic adaptor M28/M29 was added to the ends of the genomic DNA's by T4 DNA ligase. Two rounds of hybridization with $5^{\prime}$ biotin-labeled oligonucleotide (TGn and GAn) and capture by streptavidin-coated magnetic beads (Dynabeads, Dynal $\mathrm{GmbH}$ ) were carried out. The enriched genomic products were amplified using adaptor primer M28 and were cloned into plasmid vectors (pGEM3Z+, Promega). Positive microsatellite clones were identified by dot blot hybridization with appropriate mixes of biotin labelled SSR oligonucleotides.

Sequences were obtained by amplifying an aliquot of frozen bacterial culture from positive hybridizing colonies

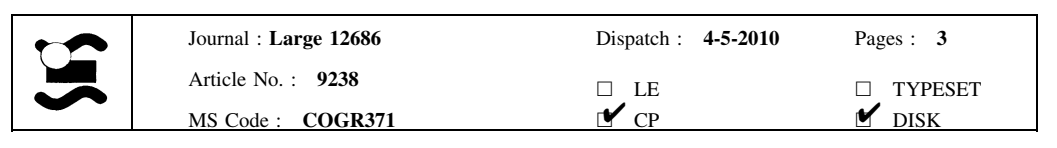


using M13 universal forward and reverse primers, treated with Exonuclease I and Shrimp alkaline phosphatase, and then sequenced from both orientations using ABI3730 capillary electrophoresis (NAPS Service, University of British Columbia). For 18 microsatellite loci isolated from these libraries, PCR primers complementary to the flanking regions of loci were designed with c. $40 \% \mathrm{GC}$ and avoiding palindromic sequence motifs. Ten microsatellites were scored as "useful" based on good amplification of polymorphic sized bands from single copy genomic target but only nine have given PCR polymorphic results and were considered robust and predictable enough for further analyses (Table 1).

Each $25 \mu \mathrm{l}$ PCR reaction contained approximately $20 \mathrm{ng}$ of DNA, 10 pmol of each primer, as well as PCR Master Mix (Reddy-Mix, ABgene, Surrey, UK) that included 0.625 units of Taq DNA polymerase, $75 \mathrm{mM}$ Tris- $\mathrm{HCl}, 20 \mathrm{mM}(\mathrm{NH} 4)_{2} \mathrm{SO}_{4}, 0.01 \%$ Tween20, $1.5 \mathrm{mM}$ de $\mathrm{MgCl}_{2}$, and $0.2 \mathrm{mM}$ of each dNTP. Forward primers were colour-labeled at the $5^{\prime}$-end with 6-FAM, PET, NED or VIC.

In general, amplifications were carried out using the following thermal cycling conditions: 3 min denaturation at $95^{\circ} \mathrm{C}, 35$ cycles of $30 \mathrm{~s}$ denaturation at $95^{\circ} \mathrm{C}, 30 \mathrm{~s}$ at annealing temperature, and $1.5 \mathrm{~min}$ elongation at $72^{\circ} \mathrm{C}$; followed by $5 \mathrm{~min}$ elongation at $72^{\circ} \mathrm{C}$. The products were detected using an ABI 3100 Genetic Analyzer and fragment sizes were determined using GenESCAN v. 2.02 and GENOTYPER v. 1.1 (Applied Biosystems, Inc.).

Examination of the microsatellite profiles shows that $S$. aria individuals have up to three alleles per locus. The cloned sequences in microsatellite loci confirmed that the polyploidy status of the plants. We are not able to determinate the exact number of copies of each allele because we do not know allele dosage in those individuals with partial heterozygoty. We identified allele peak profiles at each locus and assigned a phenotype to each individual.

Analysis of $S$. aria microsatellites used the phenotypebased statistics in the FDASH program (Obbard et al. 2006) that can measures diversity in terms of the total number of allelic phenotypes in the population. Because allopolyploids are derived from interspecific hybridization and therefore comprise at least two different genomes, this program assumes the sharing of alleles between isoloci must be owing to common ancestry. So, using a single allelic-phenotype diversity/statistic $\left(H^{\prime}\right)$ that measures diversity as the average number of alleles by which pairs of individuals differ plus a population differentiation measure $\left(F_{S T}^{\prime}\right)$ which is analogous to $F_{S T \text {; }}$ we can capture essential information regarding genetic diversity in polyploids.

The nine $S$. aria microsatellite loci are highly variable with a mean of 9.255 alleles/locus and phenotype diversities across loci $\left(H_{T}^{\prime}\right)$ ranging from 0.653 to 0.847 with a mean value of $0.742 ; F_{s t}$ mean value was 0.428 (Table 2 ).

Table 1 Primer sequences and characteristics of nine microsatellite loci from natural populations of Sorbus aria

\begin{tabular}{|c|c|c|c|c|c|c|}
\hline Locus & Repeat motif & PCR primer sequence $\left(5^{\prime} \rightarrow 3^{\prime}\right)$ & $T_{a}\left({ }^{\circ} \mathrm{C}\right)$ & $\begin{array}{l}\text { Size of cloned allele } \\
\text { (size-range) in bp }\end{array}$ & Fluorescent label & $\begin{array}{l}\text { GeneBank } \\
\text { accession no }\end{array}$ \\
\hline $\mathrm{SA} 01^{\mathrm{a}}$ & $(\mathrm{GA})_{13}$ & $\begin{array}{l}\text { F: ATGGAGTTGAGCTCCACATC } \\
\text { R: GGTGGAGGGACAATTGTGTC }\end{array}$ & 60 & $229(212-254)$ & 6-FAM (blue) & FN563114 \\
\hline $\mathrm{SA} 02^{\mathrm{b}}$ & $(\mathrm{GA})_{16}$ & $\begin{array}{l}\text { F: CTAGGTATCATCTCCGACCA } \\
\text { R: ACGTAGCACTGAATGGTATAG }\end{array}$ & 60 & $293(270-325)$ & NED (yellow) & FN563115 \\
\hline $\mathrm{SA} 03^{\mathrm{a}}$ & $(\mathrm{GA})_{12}$ & $\begin{array}{l}\text { F: CACTTCTTCСTGCTGTTTGG } \\
\text { R: ACTACTGCTACTTCTGTGGG }\end{array}$ & 60 & 234 (206-249) & VIC (green) & FN563116 \\
\hline $\mathrm{SA} 06^{\mathrm{a}}$ & $(\mathrm{GA})_{32}$ & $\begin{array}{l}\text { F: ATTTGATCCATGTGCGACTGCA } \\
\text { R: TGCAGCGGTTGCAGATTGCA }\end{array}$ & 60 & 297 (248-297) & PET (red) & FN563117 \\
\hline $\mathrm{SA} 07^{\mathrm{a}}$ & $(\mathrm{GA})_{15}$ & $\begin{array}{l}\text { F: ACGTTTTCAGTATGATGGCC } \\
\text { R: CTTCGCAGTTCATTAAGCAC }\end{array}$ & 60 & $334(325-349)$ & 6-FAM (blue) & FN563118 \\
\hline $\mathrm{SA} 08^{\mathrm{b}}$ & $(\mathrm{CT})_{16}$ & $\begin{array}{l}\text { F: CAGAGAGAGTGCACTGCCT } \\
\text { R: GAATTCTTGGCAGTTTGCCT }\end{array}$ & 60 & 249 (233-287) & 6-FAM (blue) & FN563119 \\
\hline $\mathrm{SA} 09^{\mathrm{a}, \mathrm{c}}$ & & F: CTTGTTGGACGGATTTCTTC & 60 & 174 (161-197) & NED (yellow) & FN563120 \\
\hline $\mathrm{SA} 14^{\mathrm{a}}$ & & $\begin{array}{l}\text { F: ATGGATTTAGGTTAACAGTTGTC } \\
\text { R: GAGGTAAAACCTACCAGTATAC }\end{array}$ & 57 & $203(197-232)$ & PET (red) & FN563121 \\
\hline SA19. $1^{\mathrm{a}}$ & & $\begin{array}{l}\text { F: AAGTTTACAAGAGTGTGTTCAG' } \\
\text { R: GAATTCATGAAAGCAGCTAATG }\end{array}$ & 60 & $241(212-250)$ & VIC (green) & FN563122 \\
\hline
\end{tabular}

$T_{a}=$ Annealing temperature

${ }^{\mathrm{a}} \mathrm{PCR}$ Master Mix (AB gene) $\mathrm{MgCl}_{2} 1.5 \mathrm{mM},{ }^{\mathrm{b}} \mathrm{PCR}$ Master Mix (AB gene) $\mathrm{MgCl}_{2} 2.5 \mathrm{mM}$. ${ }^{\mathrm{c}}$ Final elongation: $30 \mathrm{~min}, 72^{\circ} \mathrm{C}$

\begin{tabular}{|l|lll|}
\hline & Journal : Large 12686 & Dispatch : 4-5-2010 & Pages : $\mathbf{3}$ \\
& Article No. : $\mathbf{9 2 3 8}$ & $\square_{\text {LE }}$ & $\square$ TYPESET \\
MS Code : COGR371 & $\boldsymbol{\sim}_{\mathrm{CP}}$ & $\boldsymbol{\sim}_{\text {DISK }}$ \\
\hline
\end{tabular}


Table 2 Patterns of variability at individual microsatellite and genetic diversity analysis across all populations of Sorbus aria

\begin{tabular}{|c|c|c|c|c|c|c|c|}
\hline Locus & $A$ & $A v A$ & $P$ & $A v P$ & $H_{s}^{\prime}$ & $H_{T}^{\prime}$ & $F_{S T}^{\prime}$ \\
\hline SA01 & 5.000 & 3.033 & 5.000 & 2.462 & 0.295 & 0.653 & 0.547 \\
\hline SA02 & 9.000 & 5.680 & 7.000 & 3.680 & 0.342 & 0.681 & 0.498 \\
\hline SA03 & 10.000 & 6.602 & 7.000 & 3.269 & 0.449 & 0.734 & 0.388 \\
\hline SA06 & 9.000 & 4.897 & 8.000 & 3.897 & 0.473 & 0.763 & 0.380 \\
\hline SA07 & 8.000 & 5.875 & 11.000 & 5.688 & 0.627 & 0.847 & 0.260 \\
\hline SA08 & 10.000 & 5.062 & 12.000 & 5.639 & 0.468 & 0.804 & 0.418 \\
\hline SA09 & 10.000 & 5.680 & 6.000 & 3.144 & 0.358 & 0.690 & 0.480 \\
\hline A14 & 14.000 & 7.588 & 12.000 & 5.887 & 0.495 & 0.808 & 0.387 \\
\hline SA19,1 & 00 & 4.211 & 7.000 & 58 & 50 & 0.693 & 0.496 \\
\hline $\begin{array}{c}\text { Average } \\
\text { across } \\
\text { loci }\end{array}$ & 9.255 & 5.422 & 8.367 & 4.065 & 0.429 & 0.742 & 0.428 \\
\hline
\end{tabular}

$A$ total number of alleles, $A v A$ average number of different allele per sample, $P$ total number of phenotypes seen, $A v P$ average number phenotypes per sample, $H_{S}^{\prime}$ phenotype diversity within sample, $H_{T}^{\prime}$ phenotype diversity across all samples, $F_{S T}^{\prime}=\left(\mathrm{H}_{\mathrm{T}}^{\prime}-\mathrm{H}_{\mathrm{S}}^{\prime}\right) / \mathrm{H}_{\mathrm{T}}^{\prime}$ measure of genetic differentiation among populations

123 Acknowledgments We thank Ángel Bañares, Manuel Marrero, 124 Eduardo Carqué, Manuel Izquierdo (Parque Nacional del Teide, 125 Tenerife), Ángel Palomares and Álvaro Rodríquez Felipe (Parque 126 Nacional Caldera del Taburiente, La Palma), Alicia Escandell and 127 Nancy Cabanillas for assistance in collecting Sorbus samples. Also, 128 we thank Craig Newton for microsatellite library development and 129 Pilar García for instruct us in cloning protocols. This research was funded by the Ministerio de Medio Ambiente y Medio Rural y Organismo Autónomo de Parques Nacionales (2/2005).

\section{References}

Cabezudo B, Hernández-Bermejo JE, Herrera CM, Muñoz J, Valdés B (2000) Libro rojo de la flora silvestre amenazada de Andalucía II: especies vulnerables. Junta de Andalucía, Sevilla, España

Campbell CS, Donoughue MJ, Baldwin BG, Wojciechowski MF 136 (1995) Phylogenetic relationship in Maloideae (Rosaceae): 137 evidence from sequences of internal transcribed spacers of 138 nuclear ribosomal DNA and its congruence with morphology. Am J Bot 82:903-918

Chester M, Cowan RS, Fay MF, Rich TCG (2007) Parentage of endemic Sorbus L (Rosaceae) species in the British Isles: evidence from plasmid DNA. Bot J Linn Soc 154:291-304

Doyle JJ, Doyle JL (1987) A rapid DNA isolation procedure for small quantities of fresh leaf tissue. Phytochem Bull Bot Soc Amer 19:11-15

Khasa PD, Newton CH, Rahman MH, Jaquish B, Dancik BP (2000) Isolation, characterization and inheritance of microsatellite loci in alpine and western larch. Genome 43:439-448

Nelson-Jones EB, Briggs D, Smith AG (2002) The origin of intermediate species of the genus Sorbus. Theor Appl Genet 105:953-963

Obbard DJ, Harris SA, Pannekk JR (2006) Simple allelic-phenotype diyersity and differentiation statistics for allopolyploids. Heredity 97:296-303

Robertson KR, Phipps JB, Rohrer JR, Smith PG (1991) A synopsis of genera in Maloideae (Rosaceae). Syst Bot 16:376-394
137
138

139

140

141

142

143

144

145

146

147

148

149

150

151

152

153

154

155

156

157

158

\begin{tabular}{|l|ll|} 
Journal : Large 12686 & Dispatch : 4-5-2010 & Pages : 3 \\
Article No. : $\mathbf{9 2 3 8}$ & $\square$ LE & $\square$ TYPESET \\
MS Code : COGR371 & $\sim_{\text {CP }}$ & $\checkmark$ DISK \\
\hline
\end{tabular}

